\title{
KINETIKA REAKSI ENZIMATIS EKSTRAK KASAR ENZIM SELULASE BAKTERI SELULOLITIK HASIL ISOLASI DARI BEKATUL
}

\author{
Dyah Ayu Saropah, Akyunul Jannah, Anik Maunatin
}

Jurusan Kimia, Fakultas Sains dan Teknologi, UIN Maulana Malik Ibrahim Malang

\begin{abstract}
Bran rice is a by-product of rice into rice milling process, the cellulose content of $40-60 \%$, so the potential as a carbon source for the growth of microorganisms such as bacteria to produce enzymes particularly cellulolytic bacteria. The purpose of the study was to determine the diversity of the characters from the cellulolytic bacterial isolates and optimum conditions enzyme (cellulase enzymes rough) so that they can hydrolyze the cellulose to glucose with either rice bran. The characterization includes the determination of $\mathrm{pH}$, temperature and time of optimum crude extract of bacterial cellulolytic enzyme cellulase, determination of Vmax and $\mathrm{Km}$ and molecular mass determination of cellulase.

Research methods include making media, regeneration of isolates, bacterial growth curve manufacturing, production of cellulase enzymes from bacterial cellulolytic rough at the optimum conditions, the kinetics of enzymatic reaction: substrate concentration factor of the reaction rate (with variation of the concentration of $0.50 \%, 0.75 \%, 1,00 \%, 1.25 \%$ and $1.50 \%$ (w / v)) followed by calculating the Vmax and $\mathrm{Km}$.

The results showed that the enzyme cellulase of cellulolytic bacteria is olated from rice bran result that has optimum conditions at $\mathrm{pH} 7.5$, temperature $50^{\circ} \mathrm{C}, 40$ min incubation time to produce Vmax 0.0086 units / $\mathrm{mL}$ and $\mathrm{Km} 1.694 \%$.
\end{abstract}

Key words : kinetics ofenzymatic reaction, selullase enzyme and rice bran

\section{ABSTRAK}

Bekatul merupakan hasil samping dari proses penggilingan padi menjadi beras, dengan kandungan selulosa 40-60\% sehingga berpotensi sebagai sumber karbon bagi pertumbuhan mikroorganisme seperti bakteri yang dapat menghasilkan enzim khususnya bakteri selulolitik. Tujuan dari penelitian ini untuk mengetahui keragaman karakter dari isolat-isolat bakteri selulolitik dan kondisi optimum enzim (enzim selulase kasar) tersebut sehingga dapat menghidrolisis selulosa dalam bekatul menjadi glukosa dengan baik. Kinetika reaksi enzimatis dengan mengukur Vmaks dan Km.

Metode penelitian meliputi pembuatan media, peremajaan isolat, pembuatan kurva pertumbuhan bakteri, produksi enzim selulase kasar dari bakteri selulolitik pada kondisi optimum, kinetika reaksi enzimatis : faktor konsentrasi substrat terhadap laju reaksi (dengan variasi konsentrasi 0,50\%; 0,75\%; 1,00\%; $1,25 \%$ dan $1,50 \%(\mathrm{~b} / \mathrm{v})$ ) dilanjutkan dengan menghitung Vmaks dan $\mathrm{Km}$.

Hasil penelitian menunjukkan bahwa enzim selulase dari bakteri selulolitik hasil isolasi dari bekatul yang mempunyai kondisi optimum pada $\mathrm{pH} 7,5$, suhu $50{ }^{\circ} \mathrm{C}$, waktu inkubasi 40 menit dengan menghasilkan $\mathrm{V}_{\max } 0,0086$ Unit/mL serta $\mathrm{K}_{\mathrm{m}} 1,694 \%$.

Kata kunci : kinetika reaksi enzimatis, enzim selulase dan bekatul

\section{PENDAHULUAN}

Limbah pertanian berupa selulosa dan hemiselulosa merupakan masalah penting di Indonesia, hal ini disebabkan kandungan material selulosa yang melimpah namun sulit didegradasi. Salah satu dari limbah tersebut adalah bekatul. Bekatul merupakan hasil samping dari proses penggilingan padi menjadi beras. Departemen Pertanian (2007) menyebutkan bahwa konsumsi beras masyarakat Indonesia masih tergolong tinggi yaitu 139.15 Kg per kapita per tahun. Peningkatan produksi dan konsumsi padi ini berimbas pula pada peningkatan produk samping penggilingan padi, salah satunya adalah bekatul. Sampai saat ini pemanfaatan bekatul masih sangat terbatas, yaitu hanya sebagai pakan 
ternak. Sehingga, perlu adanya pemanfaatan limbah padi (Bekatul).

Irawadi (1990), menyatakan bahwa limbah pertanian seperti bekatul dan tongkol jagung mengandung selulosa (40-60\%), hemiselulosa $(20-30 \%)$, dan lignin $(15-30 \%)$. Selain itu juga menurut Ardiansyah (2010), bekatul mengandung $14,9 \%$ protein; 12,5 \% lemak; 32,8\% selulosa; 42,8 \% hemiselulosa; 24,4 \% lignin; 2,1 \% abu; dan 3,6 \% air, sehingga dapat digunakan sebagai bahan pakan ternak, sumber energi, sebagai sumber karbon bagi pertumbuhan mikroorganisme seperti bakteri yang dapat menghasilkan enzim khususnya bakteri selulolitik.

Enzim dapat diproduksi oleh mikroorganisme seperti fungi dan bakteri. Salah satu jenis enzim yang banyak dihasilkan oleh mikroorganisme adalah enzim selulase. Mikroorganisme penghasil selulase dari kelompok bakteri memiliki tingkat pertumbuhan yang cepat sehingga waktu yang dibutuhkan untuk memproduksi selulase menjadi lebih pendek (Alam et al., 2004). Cendawan diketahui paling baik dalam mendegradasi selulosa, tetapi bakteri menjadi pilihan utama, ha1 ini dikarenakan bakteri memiliki ukuran molekul selulase yang lebih kecil dibandingkan dengan cendawan sehingga lebih mudah untuk berdifusi kejaringan tumbuhan yang mengandung selulosa (Li \& Gao 1997).

Enzim selulase yang dihasilkan oleh mikroorganisme mempunyai karakteristik yang berbeda-beda, hal ini dipengaruhi oleh faktor lingkungan seperti, suhu, $\mathrm{pH}$ lingkungan tempat enzim bekerja, konsentrasi substrat tertentu dan waktu inkubasi. Semua enzim bekerja dalam rentang suhu tertentu pada tiap jenis mikroorganisme. Sebagian besar enzim memiliki aktivitas optimum pada suhu 20-50 ${ }^{\circ} \mathrm{C}$ termasuk dalam golongan mesozim (Volk dan Wheeler, 1984). Peningkatan suhu eksternal secara umum akan meningkatkan kecepatan reaksi kimia enzim, tetapi kenaikan suhu yang terlalu tinggi akan menyebabkan terjadinya denaturasi enzim yaitu berubahnya struktur protein enzim, terutama perubahan pada ikatan ionik dan ikatan hidrogennya sehingga menyebabkan terjadinya penurunan kecepatan reaksi yang dikatalisis oleh enzim tersebut.

Ekstrak kasar enzim selulase dari isolat bakteri selulolitik diduga memiliki potensi dalam mendegradasi bekatul yang merupakan hasil samping dalam penggilingan padi menjadi glukosa sehingga dapat digunakan sebagai bahan baku yang potensial untuk dijadikan pangan fungsional. Oleh karena itu, Diperlukan enzim selulase dengan aktivitas tinggi yang dapat diambil dari bakteri selulolitik untuk mendegradasi limbah tersebut.

Aktivitas enzim selulase sangat berhubungan dengan kinetika enzim. Ngili (2010) menyatakan kinetika enzim berkaitan dengan pengukuran laju reaksi enzimatik serta dengan faktor-faktor yang mempengaruhi laju tersebut. Faktor-faktor penting yang mempengaruhi laju reaksi enzimatik adalah konsentrasi substrat dan enzim, $\mathrm{pH}$, suhu dan adanya kofaktor sera ion logam. Penting untuk memepelajari mengenai faktor-faktor ini.

Pada pembahasan ini akan mempelajari kinetika enzim selulase dari isolat bakteri selulolitik hasil isolasi dari bekatul yang memiliki potensi dalam hidrolisis selulosa dalam bekatul menjadi glukosa (Jannah dan Maunatin, 2011) sehingga dapat digunakan sebagai bahan baku yang potensial untuk dijadikan pangan fungsional. Kinetika enzim selulase ditinjau dari pengaruh konsentrasi substrat terhadap laju reaksi enzimatis. Analisis kuantitatif kinetika reaksi enzim dilakukan dengan asas pendekatan yaitu asas keseimbangan menurut Michaelis-Menten.

\section{Bekatul}

Di Indonesia, proses penyosohan beras umumnya dilakukan hanya dalam satu tahap saja. Dengan demikian, hasil samping dari sosohan tersebut, yaitu dedak dan bekatul, bercampur menjadi satu, sehingga limbah penggilingan padi yang berupa dedak berarti pula bekatul. 
komposisi kimia bekatul cukup tinggi: $14,9 \%$ protein; $12,5 \%$ lemak ; 32,8\% selulosa; $\quad 42,8 \%$ hemiselulosa; $24,4 \%$ lignin; $2,1 \% \quad$ abu; $3,6 \%$ air (Ardiansyah,2010).

\section{Enzim Selulase}

Enzim selulase merupakan enzim yang memegang peranan penting dalam proses biokonversi limbah-limbah organik berselulosa menjadi glukosa (Chalal, 1983). Enzim selulase dapat diperoleh dari berbagai sumber seperti tanaman, insekta dan mikroorganisme (Maranatha. 2007). Bakteri selulotik ditemukan di berbagai ekosistem. Contoh bakteri selulotik adalah Cellumonas sp, celvibrio sp., Microbispora bispora, Thermomonospora sp., Acentivibrio cellulolyticus, Bacteriodes cellulosolvent, Bacteriodes succinogenes, Ruminococcus albus, Ruminococcus flavefaciens dan Clostridium termocellum . Enzim selulosa dapat dihasilkan oleh berbagai bakteri dan fungi, aerob dan anerob, mesofil dan termofil. (Bhat and Bhat, 1997).

Enzim selulase kasar yang digunakan merupakan hasil isolasi dari bekatul dengan menggunakan media umum nutrien agar. Berdasarkan hasil isolasi bakteri yang telah dilakukan maka diperoleh 8 isolat dan didapatkan satu isolat terbaik dengan rasio zona bening sebesar 1,6 (BK 7). Hasil pengamatan morfologi koloni secara makroskopis bakteri pada media umum tampak semua koloni bakteri mempunyai warna kekuningan, putih susu, krem dan transparan, sedangkan bentuk morfologi pada semua koloni bakteri mempunyai ciri-ciri bentuk koloni bulat, elevasinya berbentuk cembung (convex) dan bertepi rata (entire). Hasil pengujian pewarnaan gram menunjukkan gram negatif. Hasil uji katalase menunjukkan hasil positif (adanya gelembung $\mathrm{O}_{2}$ ). pewarnaan endospora menunjukkan endospora positif (warna merah pada sel vegetatif.

\section{Mekanisme Kerja Enzim Selulase}

Hidrolisis selulosa terdiri dari dua tahap, yaitu degradasi selulosa menjadi selobiosa oleh endo-1,4-glukanase dan ekso-1,4 glukanase kemudian dilanjutkan dengan pemecahan selobiosa oleh $\beta-1,4$ glukosidase(Juhasz dkk., 2003).

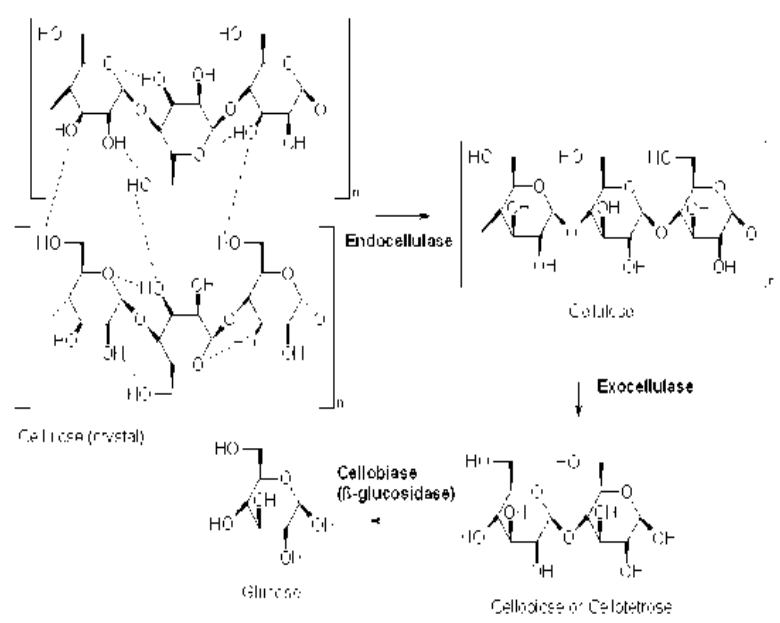

Gambar 1. Mekanisme kerja enzim selulase.

Mekanisme di atas merupakan proses hidrolisis selulosa oleh bakteri yang dilakukan dengan bantuan enzim ekstraselular yaitu Endo $\beta$-1,4-glukanase, Ekso $\beta$-1,4-glukanase dan $\beta$-glukosidase. Enzim Endo $\quad \beta$-1,4-glukanase menghidrolisis polimer secara acak dan menghasilkan molekul sellulosa sederhana. Sedangkan Ekso $\quad \beta$-1,4-glukanase menghidrolisis dua subunit glukosa pada bagian ujung sehingga menghasilkan selobiosa disakarida. Enzim $\beta$-glukosidase menghidrolisis selobiosa menjadi glukosa. Enzim memiliki kekhasan dalam mengenali dan mengikat substrat, karena enzim memiliki sisi aktif yang digunakan untuk mengikat substrat, sisi aktif yang dimiliki enzim sangat spesifik. Enzim selulase memiliki gugus aktif $-\mathrm{COOH}$ yang merupakan gugus aktif dari asam amino jenis asam aspartat (Whithers, 1995 dalam Andamari, 2003).

\section{Kinetika Reaksi Enzimatis}

Enzim merupakan protein yang mengkatalis reaksi biokimia yang secara 
kolektif membentuk metabolisme perantara. Laju awal (Vo) dari reaksi yang dikatalisis enzim meningkat dengan bertambahnya konsentrasi substrat hingga dicapai keadaan dimana penambahan substrat tidak lagi meningkatkan laju awal reaksi dan bila semua enzim dalam keadaan ES (jenuh oleh substrat) maka laju reaksi akan mencapai nilai maksimum (Vmaks).

Laju reaksi bergantung pada kondisi larutan dan konsentrasi substrat. Kondisikondisi yang menyebabkan denaturasi protein seperti temperatur tinggi, konsentrasi garam yang tinggi, dan nilai $\mathrm{pH}$ yang terlalu tinggi atau terlalu rendah akan menghilangkan aktivitas enzim. Sedangkan peningkatan konsentrasi substrat cenderung meningkatkan aktivitasnya. Untuk menentukan kelajuan maksimum suatu reaksi enzimatik, konsentrasi substrat ditingkatkan sampai laju pembentukan produk yang terpantau menjadi konstan (Radzicka dan Wolfenden, 1995).

Pada kelajuan yang maksimum $\left(V_{\max }\right)$, semua tapak aktif enzim akan berikatan dengan substrat, dan jumlah kompleks ES adalah sama dengan jumlah total enzim yang ada. Namun, $V_{\text {max }}$ hanyalah salah satu konstanta kinetika enzim. Jumlah substrat yang diperlukan untuk mencapai nilai kelajuan reaksi tertentu jugalah penting. Hal ini diekspresikan oleh konstanta MichaelisMenten $\left(K_{\mathrm{m}}\right)$, yang merupakan konsentrasi substrat yang diperlukan oleh suatu enzim untuk mencapai setengah kelajuan maksimumnya. Setiap enzim memiliki nilai $K_{\mathrm{m}}$ yang berbeda-beda untuk suatu subtrat, dan ini dapat menunjukkan seberapa kuatnya pengikatan substrat ke enzim (Radzicka dan Wolfenden, 1995).

Hasil eksperimen menunjukkan bahwa dengan konsentrasi enzim yang tetap, maka pertambahan konsentrasi substrat akan menaikkan kecepatan reaksi. Akan tetapi pada batas konsentrasi tertentu, tidak terjadi kenaikan kecepatan reaksi walaupun konsentrasi substrat diperbesar. Hal ini berdasar hukum Michaelis-Menten yang menyatakan bahwa kecepatan reaksi akan meningkat seiring dengan meningkatnya konsentrasi substrat. Kecepatan reaksi akan terus meningkat dengan nilai yang semakin kecil hingga mencapai titik batas dimana enzim jenuh dengan substrat (Poedjiadi, 2007). Titik batas ini disebut kecepatan maksimum $\left(\mathrm{V}_{\max }\right)$ (Lehninger, 1997).

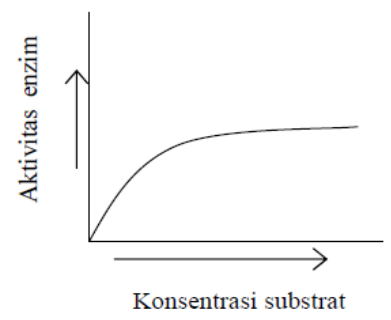

Gambar 2 Pengaruh konsentrasi substrat pada laju aktivitas enzim (Poedjiadi, 2007)

Menurut Leonor Michaelis dan Maud Menten, penggabungan enzim (E) dengan substrat $(\mathrm{S})$ merupakan reaksi yang dapat balik dan berlangsung relatif cepat membentuk kompleks enzim-substrat (ES). Selanjutnya terurai dan membentuk produk reaksi (P) dan enzim bebas (E) (Palmer, 1985).

$$
\mathrm{E}+\mathrm{S} \underset{\mathrm{k}_{1}}{\stackrel{\mathrm{k}_{1}}{\rightleftarrows}} \mathrm{ES} \stackrel{\mathrm{k}_{2}}{\longrightarrow} \mathrm{E}+\mathrm{P}
$$

Laju reaksi persamaan di atas dapat didefinisikan dalam persamaan:

$$
\mathrm{V}=\mathrm{k}_{2}[\mathrm{ES}]
$$

[ES] biasanya merupakan besaran yang tidak dapat diukur. Besaran yang dapat diukur adalah konsentrasi substrat dan konsentrasi enzim total, yaitu jumlah enzim bebas dan enzim dalam kompleks ES:

$$
[\mathrm{E}]_{\mathrm{t}}=[\mathrm{E}]+[\mathrm{ES}]
$$

Pada keadaan steady state, laju pembentukan dan penguraian kompleks ES sama:

$$
\begin{aligned}
& \mathrm{k}_{1}[\mathrm{E}][\mathrm{S}]=\mathrm{k}_{-1}[\mathrm{ES}]+\mathrm{k}_{2}[\mathrm{ES}] \\
& {[\mathrm{ES}]=\left(\frac{k 1}{k-1+k 2}\right){ }_{[\mathrm{E}][\mathrm{S}]}}
\end{aligned}
$$


Kemudian konstanta laju reaksi digabungkan menjadi satu konstanta, yaitu $\mathrm{K}_{\mathrm{M}}$ :

$\mathrm{K}_{\mathrm{M}}=\left(\frac{k 1}{k-1+k 2}\right)$

Sehingga dapat ditulis:

$\mathrm{K}_{\mathrm{M}}[\mathrm{ES}]=[\mathrm{E}][\mathrm{S}]$

$\mathrm{K}_{\mathrm{M}}[\mathrm{ES}]=[\mathrm{E}]_{\mathrm{t}}[\mathrm{S}]-[\mathrm{ES}][\mathrm{S}]$

$[\mathrm{ES}]\left(\mathrm{K}_{\mathrm{M}}+[\mathrm{S}]\right)=[\mathrm{E}]_{\mathrm{t}}[\mathrm{S}]$

$[\mathrm{ES}]=\frac{[E]_{t}[S]}{K_{M}+[S]}$

Selanjutnya:

$\mathrm{V}=\frac{k_{\mathbf{2}}[E]_{t}[\mathrm{~S}]}{K_{M}+[S]}$

Saat laju reaksi mencapai kecepatan maksimum $\left(\mathrm{V}_{\max }\right)$, nilai $\mathrm{K}_{\mathrm{M}} \gg[\mathrm{S}]$

Maka:

$\mathrm{V}_{\max }=\mathrm{k}_{2}[\mathrm{E}]_{\mathrm{t}}$

Akan didapat persamaan MichaelisMenten:

$\mathrm{V}=\frac{V_{\max [s]}}{K_{M}+[S]}$

Persamaan Michaelis-Menten yaitu hubungan kuantitatif antara laju reaksi enzim dan konsentrasi substrat, bila $V_{\max }$ dan $\mathrm{K}_{\mathrm{M}}$ diketahui. Karena sangat sulit untuk mencari harga $\mathrm{V}_{\max }$ dan $\mathrm{K}_{\mathrm{M}}$ secara langsung, maka persamaan tersebut harus ditransformasikan dengan metode Lineweaver-Burk yang merupakan bentuk penyederhanaan terhadap rumus Michaelis (Murray, et al., 1999):

$$
\frac{1}{\bar{V}}=\frac{\frac{1}{V_{\max }+K_{M}}}{V_{\max \mathbf{m}}}
$$

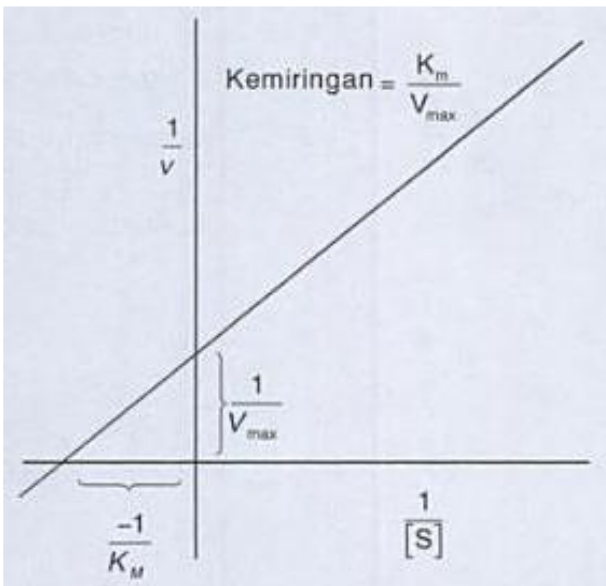

Gambar 3 Grafik hubungan antara 1/V dengan $1 /[\mathrm{S}]$

Data untuk menghitung harga $\mathrm{V}_{\text {max }}$ dan $K_{M}$ adalah dengan membuat grafik hubungan antara $\frac{1}{V}$ vs $\frac{1}{[S]}$ sehingga diperoleh persamaan linear, $y=a x+b$, dimana $\mathrm{y}=\frac{1}{\bar{V}}$ dan $\mathrm{x}=\frac{1}{\overline{[S]}}$. Intersep garis (b) yang didapat dari persamaan linear adalah $\frac{1}{V_{\max }}$ dan slope (a) merupakan $\frac{K_{M}}{V_{\max }}$ (Suharto, 1995).

\section{METODE PENELITIAN}

\section{Pembuatan Media}

\section{1.a. Pembuatan Media CMC Agar}

Media yang digunakan adalah media CMC agar yang terdiri dari 1 gr CMC; 0,04 g $\mathrm{MgSO}_{4} \cdot 7 \mathrm{H}_{2} 0 ; 0,15 \mathrm{~g} \quad \mathrm{KNO}_{3} ; 0,1 \mathrm{~g}$ $\mathrm{K}_{2} \mathrm{HPO}_{4} ; 0,004 \mathrm{~g} \mathrm{CaCl}_{2} .2 \mathrm{H}_{2} \mathrm{O} ; 0,4 \mathrm{~g}$ yeast extract; dan 3,4 agar. Semua bahan dimasukkan dalam beaker gelas $250 \mathrm{ml}$ dan dicampur dengan aquades sebanyak 100 $\mathrm{mL}$, dipanaskan sampai mendidih sambil diaduk hingga larut, kemudian media tersebut dimasukkan ke dalam enlenmeyer dan ditutup kapas, kemudian disterilisasi dalam autoklaf menggunakan suhu $121{ }^{\circ} \mathrm{C}$ dan tekanan $1 \mathrm{~atm}$ selama 15 menit.

\section{1b. Pembuatan Media CMC Cair}

Media yang digunakan adalah media CMC yang terdiri dari 1 gr CMC; 0,04 g 
$\mathrm{MgSO}_{4} \cdot 7 \mathrm{H}_{2} 0 ; 0,15 \mathrm{~g} \mathrm{KNO}_{3} ; 0,1 \mathrm{~g} \mathrm{~K}_{2} \mathrm{HPO}_{4}$; $0,004 \mathrm{~g} \mathrm{CaCl}$. $2 \mathrm{H}_{2} 0$; dan $0,4 \mathrm{~g}$ yeast extract. Semua bahan dimasukkan dalam beaker gelas $250 \mathrm{ml}$ dan dicampur dengan aquades sebanyak $100 \mathrm{~mL}$, dipanaskan sampai mendidih sambil diaduk hingga larut, kemudian media tersebut dimasukkan ke dalam enlenmeyer dan ditutup kapas, kemudian disterilisasi dalam autoklaf menggunakan suhu $121{ }^{\circ} \mathrm{C}$ dan tekanan 1 atm selama 15 menit.

\section{Peremajaan Isolat}

Peremajaan bakteri dilakukan dengan mengambil 1 ose bakteri selulolitik hasil isolasi dari bekatul kemudian digoreskan pada media CMC agar miring 1 $\%$ (prosedur 3.5.1.1) dan diinkubasi selama 24 jam pada suhu ruang (Nurhamida, 2008). Hasil peremajaan digunakan untuk penentuan kurva tumbuh dan kurva aktivitas selulase.

\section{Pembuatan Kurva Pertumbuhan Bakteri dan Aktivitas Selulase}

Pembuatan kurva pertumbuhan dilakukan dengan cara menginokulasikan sebanyak 2 ose isolat hasil peremajaan ke dalam $200 \mathrm{~mL}$ medium CMC broth $1 \%$ (prosedur 3.5.1.2) kemudian diinkubasi pada shaker incubator dengan kecepatan $125 \mathrm{rpm}$ pada suhu ruang selama 18 jam, diambil sebanyak $25 \mathrm{~mL}$ dan dipindahkan dalam $250 \mathrm{~mL}$ medium CMC broth $1 \%$, kemudian diambil $4 \mathrm{~mL}$ tiap 4 jam sekali dan diukur densitas optik (OD) dan aktivitas selulasenya hingga mencapai fase awal kematian. Densitas optik (OD) diukur menggunakan spektrofotometer Uv-vis pada panjang gelombang $600 \mathrm{~nm}$. Kurva pertumbuhan ditentukan dengan membuat plot antara waktu dan densitas optiknya. Sedangkan aktivitas selulase ditentukan dengan mengukur kadar gula reduksi dengan metode Nelson-Somogyi.

\section{Produksi Enzim Selulase Kasar dari Bakteri Selulolitik}

Isolat bakteri selulolitik diinokulasikan sebanyak 2 ose dalam 200 $\mathrm{mL}$ media CMC broth $1 \%$ (prosedur
3.5.1.2), dan diinkubasi pada shaker incubator pada suhu ruang hingga mencapai fase eksponensial (prosedur 3.5.3). Ekstrak kasar enzim diperoleh dengan mensentrifugasi kultur pada kecepatan $3.000 \mathrm{rpm}$ selama 15 menit pada suhu $4{ }^{\circ} \mathrm{C}$ (Heck et al., 2002), supernatan yang diperolah adalah ekstrak kasar enzim selulase, dan digunakan untuk pengujian karakterisasi enzim selulase.

\section{Kinetika Reaksi Enzimatis : Penentuan $V_{\text {max }}$ dan $K_{m}$ Ekstrak Kasar} Selulase

Penentuan $\mathrm{V}_{\max }$ dan $\mathrm{K}_{\mathrm{m}}$ ditentukan dengan cara menguji aktivitas selulase pada konsentrasi substrat dengan variasi konsentrasi $0,50 \% ; 0,75 \% ; 1,00 \% ; 1,25$ $\%$ dan $1,50 \%(\mathrm{~b} / \mathrm{v})$ dan dilakukan pada suhu $50{ }^{\circ} \mathrm{C}, \mathrm{pH} 7,5$, dan waktu inkubasi selama 40 menit.

Sebanyak $1 \mathrm{~mL}$ substrat CMC 0,50 $\% ; 0,75 \% ; 1,00 \% ; 1,25 \%$ dan $1,50 \%$ (b/v) yang sudah dilarutkan dalam larutan buffer dengan $\mathrm{pH}$ 7,5 dimasukkan dalam 5 tabung reaksi yang berbeda, kemudian ditambah $1 \mathrm{~mL}$ ekstrak kasar selulase pada masing-masing tabung reaksi (Khabbah, 2007).

Masing-masing sampel kemudian dïnkubasi pada suhu $50{ }^{\circ} \mathrm{C}$ dengan waktu inkubasi 40 menit. Setelah itu dididihkan selama 15 menit untuk menginaktivasi enzim tersebut kemudian didinginkan pada suhu ruang. Aktivitas enzim pada variasi konsentrasi substrat tersebut dianalisis dengan menggunakan metode NelsonSomogyi.

\section{Pengukuran Aktivitas Enzim Selulase}

\section{5a. Penentuan panjang Gelombang Optimum Larutan Glukosa dengan Metode Nelson-Somogyi}

Larutan stok glukosa standart 100 ppm (10 mg glukosa anhidrat/ $100 \mathrm{~mL}$ aquades) kemudian dipipet $1 \mathrm{~mL}$, lalu dimasukkan dalam tabung reaksi, kemudian 
ditambahkan $1 \mathrm{~mL}$ reagen Nelson (Lampiran 2), lalu tabung tersebut ditutup.

Tabung reaksi yang berisi sampel tersebut dididihkan selama 20 menit, kemudian didinginkan hingga mencapai suhu $25{ }^{\circ} \mathrm{C}$. Langkah selanjutnya adalah menambahkan $1 \mathrm{~mL}$ reagen arsenomolibdat (Lampiran 2), kemudian dihomogenkan. Sampel kemudian diencerkan dengan aquades $7 \mathrm{~mL}$, setelah itu diukur absorbansinya pada panjang gelombang 200-800 nm. Blanko dibuat sama kecuali sampel diganti dengan air. Lalu dibuat kurva antara panjang gelombang pada sumbu X dengan absorbansi pada sumbu Y.

\section{5b.Pembuatan Kurva Baku Glukosa dengan Metode Nelson-Somogyi (Apriyantono, dkk., 1989)}

Larutan stok glukosa standart 100 ppm (10 mg glukosa anhidrat/ $100 \mathrm{~mL}$ aquades) diencerkan hingga didapatkan larutan glukosa standart dengan konsentrasi 5, 20, 35, 50, dan 65 ppm. Sampel yang telah diencerkan tersebut dipipet $1 \mathrm{~mL}$, lalu dimasukkan dalam tabung reaksi, kemudian ditambahkan $1 \mathrm{~mL}$ reagen Nelson (Lampiran 2), lalu tabung tersebut ditutup.

Tabung reaksi yang berisi sampel tersebut dididihkan selama 20 menit, kemudian didinginkan hingga mencapai suhu $25{ }^{\circ} \mathrm{C}$. Langkah selanjutnya adalah menambahkan $1 \mathrm{~mL}$ reagen arsenomolibdat (Lampiran 2), kemudian dihomogenkan hingga semua endapan $\mathrm{Cu}_{2} \mathrm{O}$ terlarut sempurna. Campuran selanjutnya ditambah dengan $7 \mathrm{~mL}$ aquades dan dikocok, kemudian diukur absorbansinya pada panjang gelombang $751 \mathrm{~nm}$. Kurva baku dibuat dengan menghubungkan antara konsentrasi larutan baku glukosa dengan absorbansinya.

\section{5c. Analisis Kadar Glukosa dengan Metode Nelson-Somogyi}

Sampel yang akan dianalisis dimasukkan dalam tabung reaksi, kemudian ditambahkan $1 \mathrm{~mL}$ reagen Nelson (Lampiran 2), lalu tabung tersebut ditutup rapat. Sampel kemudian dididihkan selama
20 menit. Langkah selanjutnya sampel didinginkan hingga mencapai suhu $25{ }^{\circ} \mathrm{C}$ lalu ditambahkan $1 \mathrm{~mL}$ reagen arsenomolibdat (Lampiran 2) dan dikocok sehingga endapan $\mathrm{Cu}_{2} \mathrm{O}$ larut sempurna. Kemudian ditambahkan $6 \mathrm{~mL}$ aquades lalu dikocok hingga homogen kemudian diukur absorbansinya dengan panjang gelombang $751 \mathrm{~nm}$. Blanko dibuat sama tetapi tidak menggunakan enzim (Apriyantono, dkk, 1989).

\section{HASIL DAN PEMBAHASAN}

Penentuan kondisi optimum ekstrak kasar selulase bakteri selulolitik hasil isolasi dari bekatul dilakukan melalui beberapa tahap, yakni: peremajaan isolat, pembuatan kurva pertumbuhan dan produktivitas gula reduksi untuk mengetahui fase pertumbuhan bakteri dengan produksi gula reduksi tertinggi yang kemudian digunakan sebagai waktu panen atau produksi enzim selulase kasar, serta penentuan kondisi optimum enzim yang meliputi $\mathrm{pH}$, suhu, waktu inkubasi serta konsentrasi substrat. Aktivitas selulase diukur berdasarkan kadar gula reduksi yang dihasilkan menggunakan metode NelsonSomogyi.

\section{Peremajaan Bakteri Selulolitik}

Peremajaan bakteri selulolitik dilakukan pada media NA (Nutrient Agar) miring sebagai media pertumbuhannya. Media ini mengandung nutrisi yang dibutuhkan untuk pertumbuhan bakteri, dimana semua unsur ini dalam bentuk persenyawaan (Irianto, 2007).

Peremajaan isolat bertujuan untuk meregenerasi atau memperbarui sel bakteri, menjaga ketersediaan nutrisi dan untuk menghindari adanya perubahan karakteristik dari kultur murni yang ditanam. Peremajaan dilakukan secara aseptis untuk menghindari adanya kontaminan yang dapat mempengaruhi pertumbuhan bakteri yaitu dengan cara memijarkan jarum ose di atas api segera sebelum dan sesudah melakukan pemindahan bakteri serta melewatkan mulut 
tabung tempat biakan di atas api segera sebelum dan sesudah memasukkan jarum dan mengambilnya serta segera mungkin menutup tabung (Sutedjo, 1996).

Peremajaan isolat dilakukan dengan cara mengambil sebanyak 1 ose bakteri selulolitik dan digoreskan secara aseptis pada media NA miring kemudian dïnkubasi selama 24 jam pada suhu ruang. Inkubasi dilakukan selama 24 jam karena pada selang waktu tersebut diasumsikan bakteri telah mengalami fase logaritmik atau eksponensial yang ditandai dengan meningkatnya jumlah sel sehingga bakteri siap dipanen (Dwijoseputro, 1994).

\section{Kurva Pertumbuhan \\ Produktivitas Gula Reduksi}

Kurva

pertumbuhan

dan

dan

produktivitas gula reduksi digunakan untuk mengetahui waktu panen enzim selulase. Waktu panen enzim ditentukan berdasarkan kadar gula reduksi tertinggi yang dihasilkan oleh kultur bakteri selulolitik pada fase pertumbuhannya.

Kurva pertumbuhan dan produktivitas gula reduksi pada penelitian ini diperoleh dengan membuat plot antara waktu inkubasi dan densitas optiknya. Mula-mula dibuat inokulum dengan cara mengambil bakteri selulolitik hasil peremajaan sebanyak 2 ose secara aseptis dan diinokulasikan ke dalam $200 \mathrm{~mL}$ media CMC (Carboxy Methyl Cellulose) broth 1 $\%$ untuk memperpendek fase adaptasi dari bakteri. Inokulum kemudian diinkubasi dalam shaker inkubator pada suhu ruang dengan kecepatan 150 rpm selama 24 jam untuk mengatur aerasi serta memperlancar transfer nutrisi ke dalam sel. Langkah selanjutnya, diambil inokulum sebanyak 25 $\mathrm{mL}$ dan diinokulasikan ke dalam $250 \mathrm{~mL}$ media serupa untuk media produksi, setelah itu inokulum diambil sebanyak $4 \mathrm{~mL}$ tiap 4 jam sekali dan diukur densitas optiknya serta produktivitas gula reduksinya. Densitas optik diukur dengan spektrofotometer UV-Vis pada panjang gelombang $600 \quad \mathrm{~nm}$ sedangkan produktivitas gula reduksi ditentukan dengan mengukur kadar gula reduksi menggunakan metode Nelson-Somogyi.

Kurva pertumbuhan dan produktivitas gula reduksi yang diperoleh disajikan pada Gambar 4.

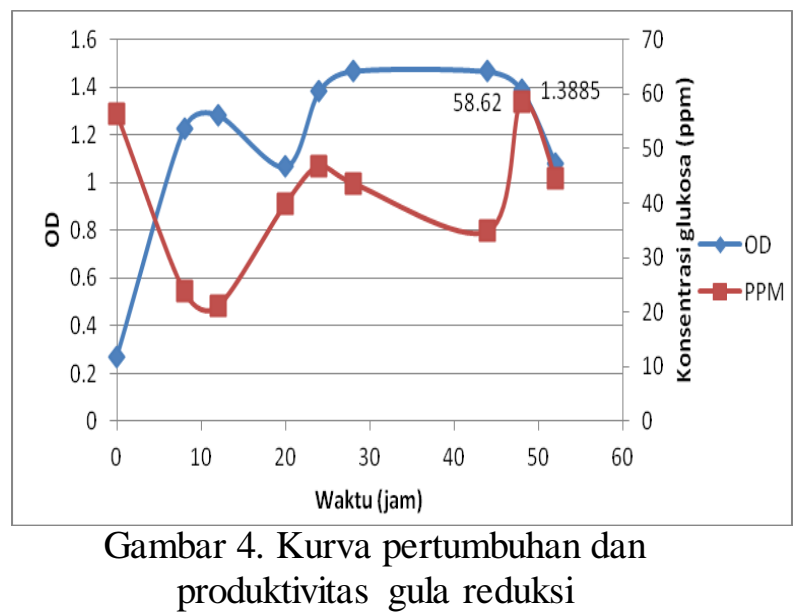

Pertumbuhan bakteri selulolitik (Gambar 4) ditandai dengan meningkatnya nilai densitas (kekeruhan) medium sejalan dengan meningkatnya lama waktu inkubasi. Tahapan fase yang terjadi pada pertumbuhan bakteri selulolitik dalam medium CMC meliputi fase lambat ( $\mathrm{Lag}$ Phase) terjadi pada jam ke-0 sampai jam ke-4 karena fase ini populasi bakteri belum mengalami perkembangbiakan, dikarenakan sel mengalami adaptasi dengan medium yang baru (Hamdiyati, 2001). Fase ini sel bakteri mulai membesar, tetapi belum membelah sehingga tidak ada pertambahan populasi (Hidayat, dkk., 2006), dan telah mempersiapkan diri untuk mensintesis berbagai jenis enzim hidrolase ekstraseluler (Brock, et al., 1986).

Fase logaritmik (Exponential Phase) terjadi pada jam ke-4 hingga jam ke-20 yang ditandai dengan bertambahnya jumlah sel dalam populasi. Hal ini karena bakteri sudah beradaptasi dengan media dan dapat melakukan reproduksi dengan pembelahan sel (Astuti dan Rahmawati, 2010). Bertambahnya jumlah sel bakteri akan meningkatkan sintesis enzim selulase untuk proses metabolisme dalam sel. Akan tetapi, setelah selulosa dalam media tumbuhnya mendekati habis maka bakteri akan 
memanfaatkan glukosa yang telah diuraikan oleh enzim selulase sebagai sumber energi dalam selnya (White, 2000), yang ditandai dengan menurunnya kadar gula reduksi yang dihasilkan.

Fase stasioner (Stationer Phase), terjadi dari jam ke-20 hingga jam ke-48. Pada fase ini mikroorganisme tidak lagi melakukan pembelahan sehingga jumlah sel cenderung tetap karena persediaan nutrisi terbatas (Mangunwidjaja, 1994). Pada jam ke-48 kadar gula reduksi yang dihasilkan meningkat, hal ini diduga enzim selulase telah mencapai waktu inkubasi yang optimal sehingga dapat menghasilkan gula reduksi yang tinggi (Gal, et.al., 1997). Setelah melewati jam ke-48 absorbansi menurun yang mungkin disebabkan banyaknya kematian sel dalam media, sehingga kadar gula reduksi yang dihasilkan juga mengalami penurunan (Dees, et.al., 1995). Berdasarkan kurva pertumbuhan dan produktivitas gula reduksi pada Gambar 4.1 waktu panen enzim adalah pada jam ke-48 dengan kadar gula reduksi tertinggi yaitu $58,62 \mathrm{ppm}$.

\section{Produksi Enzim Selulase Kasar}

Enzim selulase dari bakteri selulolitik termasuk enzim ekstraseluler sehingga dapat diekstrak melalui dinding sel dengan cara sentrifugasi. Fungsi utama enzim ekstraseluler ini adalah mengubah nutrien disekitar sel dan membawanya masuk ke dalam sel sebagai energi untuk pertumbuhan sel (Aulanni'am, 2005).

Produksi enzim selulase dilakukan dengan cara mengambil sebanyak 2 ose bakteri hasil peremajaan secara aseptis dan diinokulasikan ke dalam $200 \mathrm{~mL}$ media CMC broth $1 \%$ dan dishaker dengan kecepatan $150 \mathrm{rpm}$ pada suhu ruang selama 24 jam untuk memperpendek fase adaptasi. Inokulum kemudian diambil sebanyak 25 $\mathrm{mL}$ dan diinokulasikan ke dalam $250 \mathrm{~mL}$ media CMC broth $1 \%$ dan diinkubasi pada suhu ruang selama 48 jam. Inkubasi dilakukan selama 48 jam yang merupakan fase stasioner dengan kadar gula reduksi tertinggi yaitu 58,62 ppm dari kurva pertumbuhan dan produktivitas gula reduksi bakteri selulolitik yang terlampir pada Lampiran 3.2.

Substrat CMC dalam produksi enzim digunakan sebagai sumber karbon bagi bakteri untuk mencukupi kebutuhan energi sel dan produksi enzim (Ray, 2007). Dengan kata lain semakin banyak sumber karbon dalam media pertumbuhan maka selulase yang dihasilkan semakin meningkat. Akan tetapi kelebihan sumber karbon dapat menghambat pertumbuhan sel karena akan mengurangi jumlah oksigen dalam media sehingga menurunkan produksi selulase. Oleh karena itu, pada penelitian ini menggunakan CMC $1 \%$ berdasarkan penelitian yang telah dilakukan oleh Arifin, et al., (2006) dalam memproduksi selulase dari Bacillus pumilus EB3.

Ekstrak kasar selulase diperoleh dengan mensentrifugasi kultur bakteri dengan kecepatan 3000 rpm selama 15 menit pada suhu $4{ }^{\circ} \mathrm{C}$ untuk memisahkan sel-sel mikroorganisme yang mengendap dan supernatan yang merupakan cairan yang berisi enzim. Dalam teknik sentrifugasi pemilihan kecepatan dan gaya berat harus diperhatikan untuk memisahkan supernatan dari selnya (Rahayu, 1990). Supernatan yang dihasilkan dari $250 \mathrm{~mL}$ inokulum adalah sebanyak $220 \mathrm{~mL}$ ekstrak kasar selulase yang kemudian digunakan untuk penentuan kinetika enzim selulase dari isolat bakteri selulolitik.

\section{Parameter Kinetika Ekstrak Kasar Selulase : Penentuan $V_{\max }$ dan $K_{m}$}

Penentuan laju reaksi maksimum $\left(\mathrm{V}_{\max }\right)$ dan konstanta Michaelis-Menten (Km) merupakan hal penting yang harus dilakukan untuk mengetahui karakteristik enzim. Nilai $\mathrm{V}_{\max }$ menunjukkan tingkat kejenuhan enzim oleh substrat sedangkan $\mathrm{Km}$ menunjukkan efisiensi katalis dari enzim yang didefinisikan sebagai konsentrasi substrat tertentu pada saat kecepatan katalitik enzim mencapai setengah kecepatan maksimumnya 
(Gultom, 2001). Nilai $\mathrm{V}_{\max }$ dan $\mathrm{Km}$ ditentukan dengan cara mengukur kecepatan awal dan aktivitas selulase pada kondisi optimumnya ( $\mathrm{pH} 7,5$, suhu $50{ }^{\circ} \mathrm{C}$, dan waktu inkubasi 40 menit) pada variasi konsentrasi substrat $0,50 \% ; 0,75 \% ; 1,00$ $\%$; $1,25 \%$; dan $1,50 \%$.

Berdasarkan persamaan MichaelisMenten, hubungan antara konsentrasi substrat dengan aktivitas selulase dapat disajikan pada Gambar 5.

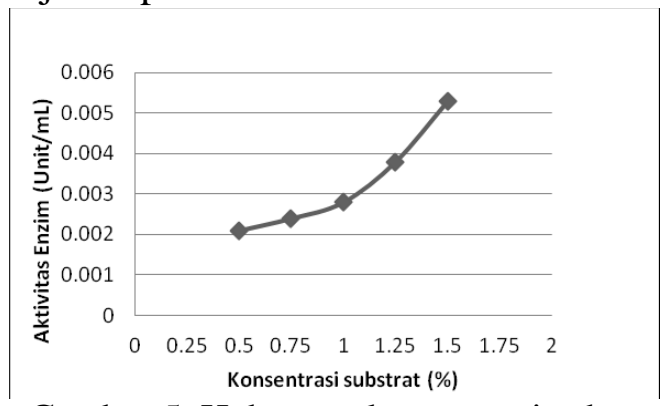

Gambar 5. Hubungan konsentrasi substrat dengan aktivitas enzim

Berdasarkan teori kinetika, semakin tinggi konsentrasi substrat maka semakin tinggi pula energi dan frekuensi benturan antar molekul sehingga semakin banyak enzim selulase yang dapat mengikat selulosa untuk membentuk kompleks enzim-glikosil yang selanjutnya akan membentuk produk berupa glukosa (Gultom, 2001). Hal ini dapat ditunjukkan pada Gambar 4.6 bahwa dengan meningkatnya konsentrasi substrat maka meningkat pula aktivitas enzim yang dihasilkan. Meskipun demikian, peningkatan aktivitas enzim akan berhenti ketika enzim sudah jenuh dengan substrat karena jumlah molar substrat sudah melampaui jumlah molar enzim setelah titik batas maksimum $\left(\mathrm{V}_{\max }\right)$ dari reaksi enzimatis.

Nilai $\mathrm{V}_{\max }$ dan $\mathrm{Km}$ dapat ditentukan dengan mentransformasikan persamaan Michaelis-Menten ke dalam persamaan Lineweaver-Burk:

$$
\frac{\frac{1}{V}=\frac{\frac{1}{V_{\max }+K_{M}}}{V_{\max }} 1}{[S]}
$$

diperoleh nilai intersep $=\frac{1}{V_{\max }, \text { slope }=}$
$\frac{K_{M}}{V_{\max I !}}, \mathrm{y}=\frac{1}{V}$, dan $\mathrm{x}=\frac{1}{[S]}$

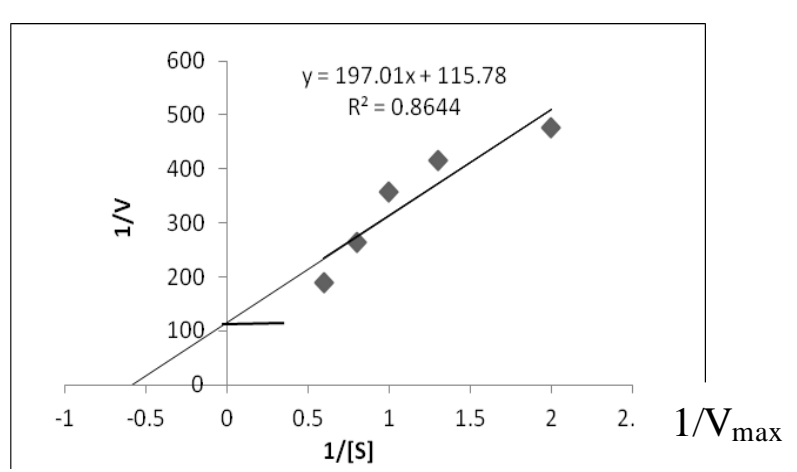

Gambar 6. Grafik hubungan 1/V dengan 1/[S] berdasarkan persamaan Lineweaver-Burk

Berdasarkan Grafik 4.7 diperoleh persamaan linear $\mathrm{y}=197,01 \mathrm{x}+115,78$, sehingga nilai $\mathrm{V}_{\max }$ sebesar 0,0086 ppm/menit dan $\mathrm{Km}$ sebesar 1,694\%. Nilai $\mathrm{V}_{\max }$ sebesar $0,0086 \quad \mathrm{ppm} /$ menit menunjukkan kecepatan maksimum enzim selulase dalam mengubah substrat selulosa menjadi glukosa sebesar 0,0086 ppm per menitnya, sedangkan konstanta MichaelisMenten ketika enzim selulase mencapai setengah dari kecepatan maksimumnya adalah sebesar 1,694\%, dengan kata lain nilai $\mathrm{K}_{\mathrm{m}}$ berfungsi sebagai ukuran konstanta disosiasi (Kd) suatu enzim. Kompleks enzim-substrat nilai $\mathrm{Kd}$ ini berbanding terbalik dengan afinitas enzim terhadap substratnya (Sadikin, 2002). Semakin kecil kecenderungan substrat dan enzim berdisosiasi maka semakin besar afinitas enzim terhadap substrat, maka kompleks ES sangat mantap, sehingga kesetimbangan reaksi kearah kompleks ES sehingga produk yang diperoleh mepunyai yield yang tinggi. Apabila nilai $\mathrm{Km}$ besar berarti enzim mempunyai afinitas rendah terhadap substrat, sehingga kesetimbangan reaksi kearah $\mathrm{E}$ $+\mathrm{S}$. 


\section{KESIMPULAN}

Kinetika reaksi enzim selulase dari bakteri selulolitik hasil isolasi dari bekatul yang mempunyai kondisi optimum pada $\mathrm{pH}$ 7,5 , suhu $50{ }^{\circ} \mathrm{C}$, waktu inkubasi 40 menit menghasilkan $\mathrm{V}_{\max } 0,0086 \mathrm{Unit} / \mathrm{mL}$ serta $\mathrm{K}_{\mathrm{m}} 1,694 \%$.

\section{DAFTAR PUSTAKA}

Alam, M. Z., Manchulur, M. A., dan Anwar, M. N. 2004. Isolation Purification, Characterization of Cellulolytic Enzyme Produced by the Isolate Streptomyces omiyaensis. Pakist J Biol Sci 7(10):16471653.

Ardiansyah. 2004. Sehat dengan Mengkonsumsi Bekatul. Suara Pembaruan 23 Agustus.

Beguin, P dan Aubert, J. P. 1992. Cellulose. Encyclopedia Microbiology. 467408.

Budiman, A dan Sigit, S. 2008. Pengaruh Konsentrasi Substrat, Lama Inkubasi dan $\mathrm{pH}$ dalam Proses Isolasi Enzim Xylanase dengan menggunakan Media Jerami Padi. Karya Ilmiah. Semarang : Teknik Kimia Undip.

Chaplin, M. 2002. Glucose from Cellulose. Diakses tanggal 23 Juni 2012.

Dwijoseputro, D. 1994. Dasar-Dasar Mikrobiologi. Jakarta: Djambatan.

Furnier, F. 1995. Current Protocols in Food Analitical Chemistry Colorimetric Quantification of Carbohidrates. Arberta Kanada: University Of Alberta.

Girindra, A. 1993. Biokimia 1. Jakarta: PT Gramedia.

Gultom, T. 2001. Biokimia Struktur dan Fungsi. Yogyakarta: UNY Press.

Irawadi, T. T. 1990. Selulase. Bogor: IPB PAU Bioteknologi.

Kim, H. 1995. Characterization and Substrate Specivicity of an EndoBetha-1,4-D-glukanase (Avicelase I) from An Extracelluler Multienzyme Complex of Bacillus
Circulans. J Appl Environ Microbiol 61: 959965.

Lehninger, A. L. 1997. Biochemistry. New York: Worth Publisher Inc.

Indahsari, M. N. 2012. Isolasi Bakteri Selulolitik dari Bekatul dan Uji Aktivitas Enzim Selulase pada Media dengan Berbagai Sumber Nitrogen. Skripsi. Tidak diterbitkan. Kimia. UIN Maliki Malang.

Palmer, T. 1985. Understanding Enzyme $3^{\text {rd }}$. New York: Ellishorwood Publisher.

Pelczar, M. J., dan Chan, E. C. S. 2008. Dasar-Dasar Mikrobiologi Jilid 1. Jakarta: UI Press.

Perez, J., Munos, D. J., Rubia, T., Martinez, J. 2002. Biodegradation and Biological Treatments of Cellulose, Hemicellulose and Lignin. $J$ Int Microbiol 5: 53-63.

Rahayu, K. 1990. Isolasi dan Pengujian Aktivitas Enzim. PAU Pangan dan Gizi. Yogyakarta: UGM Press.

Rahman, A. 1992. Teknologi Fermentasi. Bogor: Kerja Sama Penerbit Arcan dengan Pusat Antar Universitas Pangan dan Gizi IPB.

Somogyi, M. 1952. Notes on Sugar Determination. Journal of Biological Chemistry vol. 200, No. 1, 19-23.

Vogel, A. I. 1994. A Text Book of Macro and Semimicro Qualitative Inorganic Analysis. $4^{\text {th }} \quad E d$. Longmans: Green and Co Ltd.

Whither, S.G. dan R. Aebersold. 1995. Approaches to Labelling and Identification of Active Site Residues in Glucosidases. Jurnal of Protein Science 4: 361-372

Wong, D.W.S. 1995. Food Enzymes: Structur and Mechanism. New York: Chapman \& Hall. 104-106.

Radzicka A, Wolfenden R. (1995). "A proficient enzyme". Science 6 (267): 90-931. doi:10.1126/science.7809611 